\title{
The Impact of Entrepreneurial Characteristics on Entrepreneurial Intention of Sudanese and Omani University Students
}

\author{
Tariq Mohamed Salih Atiya \\ Department of Management, College of Commerce and Business \\ Administration, Dhofar University, Salalah, Oman \\ Zaroug Osman Bilal \\ Department of Accounting, College of Commerce and Business \\ Administration, Dhofar University, Salalah, Oman

\section{Mohamed Abulhamid}

Department of Accounting and Finance, College of Management Sciences, University of Bahri, Sudan.

Siddig Abdelrahman Shoaib

Al Jazeera College of Technology, Khartoum, Sudan

\begin{abstract}
This study aims to identify the level of availability of entrepreneurial characteristics among undergraduate students in some universities of Sudan and Oman, and test whether these characteristics have a significant impact on the entrepreneurial intention of these students. The study also intends to make comparison between the attitudes of students in Sudan and Oman towards establishing their businesses (self-employment). The sample of the study ( $\mathrm{n}=$ 574) consists of students from University of Bahri, Sudan International University, and Dhofar University. In order to achieve these objectives, the study adopted the descriptive and analytical approach and used the questionnaire as a tool for collecting primary. The findings reveal that, there is a statistically significant impact of the entrepreneurial characteristics among undergraduate students (need for achievement, self-efficacy and locus of control) on their entrepreneurial intention. The study also found that there are statistically significant differences in the views of the respondents according their universities, concerning the locus of control and entrepreneurial intention. The analysis showed that locus of control among students of Dhofar University and Sudan International University was higher than that of University of Bahri students. Furthermore, it was found that the
\end{abstract}


entrepreneurial intention among students of Dhofar University was higher than that of Sudan International University \& University of Bahri students

Keywords: Entrepreneurial characteristics, intentions, Students, Sudan, Oman

\section{Introduction}

Unemployment is growing among young people, especially among graduates of higher education institutions, which are increasing in number every year. The growing phenomenon is accompanied by the decline of the ability of public and private institutions to absorb more workers. The tendency of Sudanese and Omani university graduates to be job seekers rather than job creators and the limited number of job vacancies result in what is termed as educated unemployment (Kusmintarti, Asdani, and Riwajanti, 2017). The promotion of entrepreneurial activities has attracted a great attention from the academics, politicians and decision makers around the world. This is primarily because entrepreneurship activities generate the majority of new jobs. University students in general are particularly close to the entrepreneurial culture, as they often rely on knowledge and creativity, and thus have great motivation for entrepreneurial work. The personality traits of the individual are among the most important variables affecting his behavior, orientations and performance. Perhaps among these traits and characteristics, are those related to entrepreneurship that drives the individual towards creativity and the adoption of entrepreneurship and entrepreneurial behavior. Entrepreneurial behavior represents the ability to invent new ideas and transform them into implementable plans and project (Al- Nashmi, 2017). Many studies have confirmed that individuals' characteristics contribute significantly to encouraging them to practice entrepreneurial activities. Therefore, entrepreneurship is seen as a solution to unemployment in Sudan and Oman. However, encouraging university students to be job creators rather than job seekers, needs studying their entrepreneurial characteristics that may or may not help them in that regard. The researchers belief that some students will capitalize on their entrepreneurial characteristics to start their own business venture, thus entering the path to economic self-employment and creation of employment opportunities for others (Holienka, Holienková, \& Gál, 2015). This study is an attempt to contribute in this field.

Universities, training institutions and other organizations try to inculcate these characteristics in students with an attempt to build a conscious generation that recognizes the importance of having the skills, knowledge and abilities it needs to start entrepreneurial work. However, there is little understanding about differences in entrepreneurial characteristics and intentions among students belonging to different cultures (Wilson, Marlino, 
and Kickul. 2004). This study is an attempt to identify the level of availability of entrepreneurial characteristics among undergraduate students in some universities of Sudan and Oman, and test whether these characteristics have significant impact on the entrepreneurial intention of these students. The study also intends to make comparison between the attitudes of students in Sudan and Oman towards establishing their businesses (self-employment).

\section{Literature Review}

\subsection{The concept of entrepreneurship}

There are different views on the concept of entrepreneurship or entrepreneurs, depending on various perspectives. Some of these perspectives are based on language, other on personal characteristics, and some others depend on the organizational aspects, each of which has its own legitimacy.

From the linguistic aspect, the phrase entrepreneur derives from the French words entre, which means "between," and prendre, which means "to take." The word was used to point to individuals who "take on the risk" and mediate between dealers or who "undertake" the responsibility of of starting a new business (Barringer and Ireland, 2016, p. 6).

The personal characteristics approach considers entrepreneurship to be an individual or a characteristic of a particular person who has the ability to take the risk in part or in full. The roots of this concept are related to the psychological interpretation of individuals in different positions and roles (Hussain, 2013,). The important part of this interpretation is to identify and define the pattern of behavior that distinguishes one individual from another in a spatial and temporal circumstance that indicates the type of response to a particular situation that may be very critical.

On the other hand, the third approach takes a posture that entrepreneurship depends on the organizational dimension of the firm. Aspects like certainty, trust, creativity, the need to hedge for failure, and to reduce environmental ambiguity and diversity, which represent parameters or a part of critical success factors associated with the implementation of a particular strategy, taking into account the economic interpretation of entrepreneurship. In light of the foregoing, and regardless of the differences found in the definitions of entrepreneurship, there are some definitions that may be generally accepted (Al-Najjar and Al-Ali, 2006). Thus entrepreneurship is regarded as the process of creating something new with value through effort, capital spending, time allocation and risk tolerance.

More recent definitions that found general acceptance by the academicians and researchers are given by Hatten, (2016), who states that "Entrepreneurship is the process of identifying opportunities for which marketable needs exist and assuming the risk of creating an organization to 
satisfy them". Barringer \& Ireland, (2016) define "entrepreneurship as the process by which individuals pursue opportunities without regard to resources they currently control" (Barringer \& Ireland, 2016, p. 06). On the other hand Longenecker, et al., (2017) defined the entrepreneur as "the person who relentlessly pursues an opportunity, in either a new or an existing enterprise, to create value while assuming both the risk and the reward for her or his efforts" (Longenecker, Petty, Palich, \& Hoy, 2017, p. 06)

Based on the above, and in the context of current study, the researchers summarize the procedural definition of entrepreneurship, in line with Al Nashmi 2017, as a set of personal characteristics that enable the individual to seize opportunities and take the risk to create successful projects that generate wealth. Starting a successful business is not easy, as most of the decisions to establish and operate a business are individual decisions related to the entrepreneur alone. This reveals the importance of studying entrepreneurial characteristics for those who are interested in the studies of the entrepreneurship and entrepreneurs.

\subsection{Entrepreneurial Characteristics}

The entrepreneurial characteristics are the abilities and personality traits of the entrepreneur that he/she needs to manage his/her project successfully, in addition to the behavioral and managerial skills that enable him to succeed in his project

Kaufmann and Dant (1999:5) distinguished three models that are used to study entrepreneurship. These models are: trait, process and activities. The trait model represents an important contribution to the entrepreneurship literature. Many researches have been conducted to analyze personality traits of entrepreneurs. For example, in the study, by Sulatn, (2016), locus of control, self-confidence, the need for achievement, risk taking, and independence are taken as determinants of entrepreneurship. In study by Holienka, M. et al. (2015), on the other hand, locus of control, the need for achievement, risk taking, independence and innovativeness have been used as determinants entrepreneurial characteristics of students. Other authors list more than 18 personality traits and characteristics commonly associated with entrepreneurs. "Although no one is "born" to be an entrepreneur, there are common traits and characteristics of successful entrepreneurs" (Barringer and Ireland, 2016, p: 15). They add other characteristics such as, persuasive, self-confident, selfstarter, tenacious, and visionary, stating that these characteristics are developed over time and evolve from an individual's social context.

It is clear from the previous presentation that the behavioral practices and personality traits carried by the entrepreneur will support his success and help the success of his project. Moreover, the presentation reveals the absence of a specific list of the entrepreneurial characteristics that can be used to 
measure the human personality to determine the availability of these qualities it has. The results of many studies show different and differentiated characteristics of the entrepreneurs, so it is difficult to develop a complete and specific picture of the characteristics and behavior of the entrepreneurs. However, an entrepreneur remains the key to determining the characteristics and behaviors that distinguish him/her from others. In addition to the current characteristics and practices that the researchers have focused on, other new characteristics may be developed based on new researches in this area (AlSheikh, Melham, \& Al-Cakelike, 2009).

In the light of the above, the researchers found that the most entrepreneurial characteristics that are frequently cited in different studies in the entrepreneurship literature, including ( Holienka, Holienková, \& Gál, 2015, Sulatn, 2016, Sacral, 2017, Al-Nashmi, 2017) and which are more relevant for the nature of the current study to define the entrepreneurial profile of students, are: need for achievement, self-efficacy, and locus of control.

Need for achievement: It means that entrepreneurs are the people who feel most motivated and need for achievement, compared to ordinary people. This makes them good at choosing the relevant conditions for them to succeed in their business and achieve their challenging goals with a high degree of effectiveness (Al- Nashmi, 2017). This suggests students who have strong need for achievement may tend to have strong intention to start their own businesses. Therefore, we can propose that:

There is a statistically significant impact of the need for achievement on the entrepreneurial intention of students in Sudanese and Omani Universities

Self-efficacy: It refers to the individual's belief regarding his or her skills, abilities and resources to perform a specific task. Siva Rajah and Achchuthan (2013) point out that "self-efficacy, describes optimistic selfbeliefs to cope with a variety of difficult demands". It is generally believed that self-efficacy is an important variable that explains why people of equal ability perform differently. (Mohd, Yahya and Kamaruddin, 2012), state that the entrepreneurship research on self-efficacy concludes that it is imperative to clarify entrepreneurial intentions and behaviors, as individuals must believe that they can achieve something in starting and operating a new project before doing so.

Self-efficacy is described as a person's belief (or buoyancy) concerning his or her skills to mobilize motivation, cognitive resources and choices of action necessary to effectively perform a task within a specified context (Mohd, Yahya and Kamaruddin, 2012; Stajkovic and Luthans, 1998; Bandura, 1997). This suggests that students who believe in their skills and abilities will have strong intention to be entrepreneurs. Therefore, we can state 
There is a statistically significant impact of Self-efficacy on the entrepreneurial intention of students in Sudanese and Omani Universities

Locus of control: It means that the person is able to analyze and interpret events and people by focusing on a system he perceives himself. This perception is based on the ideas, values and traditions of others. Robinson et al. (1991) state that internal control leads to a positive entrepreneurial attitude and most students who receive entrepreneurial formation may develop a higher level of control and self-efficiency (as cited in Karimi, et... al. 2012). It can be said that the task of starting a new project requires that the individual be able to control and control the external factors affecting him. Therefore, we can propose that:

There is a statistically significant impact of Self-efficacy on the entrepreneurial intention of students in Sudanese and Omani Universities

\subsection{Entrepreneurial Intention}

Based on a literature review in the context of entrepreneurial intention it can be stated that the most often used theory is Icek Ajzen's theory of planned behavior (Basu and Virick, 2008).The theory of planned behavior, grounded in social brain research, depends on the principle that much human behavior is arranged and is in this way is purposeful behavior. The purposeful behavior is seen as being produced by a prior intent. It affirms that intention is a precise indicator of arranged behavior, particularly in situations where the behavior is hard to watch, uncommon, or includes eccentric time slacks. Thus, the entrepreneurial behavior shows these attributes and this in turn clarifies why several empirical studies of entrepreneurship have applied the theory of planned behavior to the study of entrepreneurship from a psychological perspective (Basu and Virick, 2008). So the entrepreneurial intention indicates that individuals are willing to perform a particular behavior, which is the factor that directly precedes and drives behavior, as noted by (Souitaris, Zerbinati, \& Al-Laham, 2007). The entrepreneurial intent is the willingness of people to initiate entrepreneurial activities. Some other researchers like Gupta and Bhawe, (2007) think that the planning and implementation of entrepreneurial ideas which are based on mental effort is intentional and directed towards entrepreneurial projects. Given that an individual's intentions may precede his / her actual behavior, he / she decides to start a project before discovering the relevant job opportunity or determining the type of work he wishes to enter in it (Al-Nashmi, 2017). Consequently, The strength of the intention of the individual determine the level of enthusiasm, and this in turn, is reflected in the level of actual performance that drives it towards the success of the project. That is because there is a link between the intention and the actual entrepreneurial behavior that leads to effective entrepreneurial projects (Ramadan 2013). This makes the entrepreneurial intention of great importance 
to the researchers as a field to study and to study the variables that lead to its positive reinforcement. For the purposes of the current study, the researchers define the entrepreneurial intention as: a university student's motivation to make a conscious plan to perform the behavior of setting up a business and to engage in entrepreneurial work and establish their own projects instead of waiting in line of employment (Basu and Virick, 2008)

Many studies, such as Zaidan (2011), Ramadan (2012), Sulatn (2016), and Saral, H. C. (2017), confirm that intentions are a very important predictor of behavior. The model of the current study is based on the theory of planned behavior (Ajzen, 2002), which is based on the fact that any decision to start a new project is planned rather than a reaction. The theory of planned behavior indicates that the behavior of the individual is always organized and planned, and that any behavior is always preceded by intention and desire to perform, and the stronger the intention to conduct any behavior, the higher the success rate of that behavior (Ozaralli \& Rivenburgh, 2016). According to Ajzen (2005), behavior is influenced by a variety of factors, including personal, social, and environmental factors, and therefore the researchers conclude that the entrepreneurial intention that lead entrepreneurial behavior is related to some personal characteristics and individual traits that vary from person to person, and this is what the current study aims to prove (Al-Nashmi, 2017).

\section{Previous Studies}

Al-Kasasba's 2008 study attempted to measure the degree of readiness of students of business administration at the University of Petra for entrepreneurship. The researcher chose a random sample of 213 students. The results of the study showed that $48.4 \%$ of the respondents are heading towards entrepreneurship, while $49.3 \%$ of the students are doubtful about their orientation towards entrepreneurship as they show a low level of entrepreneurship. The study also showed that there are no differences in the responses of students due to gender, age or academic year

(Zain, et al. 2010) conducted a study entitled "The intention for Entrepreneurship among business students in Malaysia". The study aimed to examine various issues, including personal characteristics and environmental factors that affect the motivation of the entrepreneurial desire of the students of the Faculty of Business in various disciplines at a public university in Malaysia. The study sample consisted of 288 students. The study found that $67.1 \%$ of the respondents had the intention to become entrepreneurs and that most of their decisions were influenced by attitudes of their family members by $18.9 \%$, academics by $18 \%$ and businessmen by $16 \%$.

The study of Nasser and Al-Amri 2011 aimed at measuring the entrepreneurial characteristics of graduate students in business administration and their impact on entrepreneurship through a comparative analytical study 
between the Arab University of Amman and University of Damascus. The researchers used the analytical descriptive approach to reach the results. They examined the impact of number of variables on the entrepreneurial work of the graduate students in business administration at the universities of Amman and Damascus, including self-control, the need for energy, the need for achievement, ambiguity, risk, awareness of time, and self-confidence. The study found that the level of entrepreneurial characteristics (self-control, need for energy, need for achievement, ambiguity, risk, awareness of time, and selfconfidence) among the respondents was moderate. There was a statistically significant impact of $22.1 \%$ of entrepreneurial characteristics among students of higher studies in business administration at the Universities of Amman and Damascus on entrepreneurial works, and the impact of $21.9 \%$ on the conduct of entrepreneurial work, and an impact of $7.8 \%$ on ambition in entrepreneurship.

Zidane 2011 conducted a study involving six Egyptian government universities to examine the relationship between the entrepreneurial characteristics of Egyptian university students and the possibility of establishing new projects after their graduation. The researcher pointed out that there is a relatively weak relationship between the characteristics of the students and the possibility of establishing their own projects after graduation

(Gibson et al., 2011) conducted a study comparing the desire and entrepreneurial tendencies of a sample of students from universities community colleges in the United States, in entrepreneurship programs at the undergraduate level. The study found that university students are fundamentally feeling that they are more willing to start small entrepreneurial projects in the future than college students

(Karimi, et... al. 2012) in their study titled "Application of Structural Equation Modeling to Assess the Impact of Entrepreneurial Characteristics on Students Entrepreneurial Intentions ", aimed to identify the effect of entrepreneurial characteristics on students' intention to organize their projects in Iranian universities using the structural equation modeling. The main findings of the study are: entrepreneurial intention is positively influenced by the self-efficacy of entrepreneurs and the need for achievement. Independence and risk-taking do not directly affect students' entrepreneurial intent to organize their projects. Creativity mediates the impact between self-efficacy of entrepreneurs and entrepreneurial intent

The study by Mohammad, A. S., \& Mahmoud, A. M. (2014), aimed at measuring the level of entrepreneurship among Taif university students and the role of the university in its development. The study found that university students possess the entrepreneurial characteristics in varying degrees, and that the university has a clear vision and mission which adopts the idea of 
entrepreneurship and reflects the interest of the university in supporting students' entrepreneurial projects.

Sulatn, S. M., (2016) conducted a study to identify the level of availability of entrepreneurial characteristics among undergraduate students, "Business Administration Specialization" in South Universities in the West Bank.

The study found that there is a high level of availability of entrepreneurial characteristics among the respondents. The study showed that there were no differences in the degree of availability of entrepreneurial characteristics among the students, due to gender, student GPA, secondary school certificate, and enrollment in youth entrepreneurship programs, while there are differences attributed to the variable such as university.

The study by Holienka, Holienková, \& Gál, (2015) aimed to measure the entrepreneurial characteristics of university students in different disciplines, and to develop implications and recommendations for entrepreneurship education programing according to the observed differences. The study results showed that that there are significant differences in the general enterprising tendency levels, as well as in levels of enterprising potential (i.e. tendency to start up and manage projects). The study concluded that students in different disciplines exhibit different rates of entrepreneurial predispositions

Al Haramsheh, H. E. (2016) investigated the attitudes of business administration students at Zarqa University toward the establishment of small entrepreneurial projects. The research problem was formulated to investigate the lack of interest or hesitance of graduate students of Business Administration, to establish their own entrepreneurial or small projects.

The most important results of the study were: the importance of directing business students to establish small entrepreneurial ventures, and it was also found that one of the main reasons that helps students to establish small entrepreneurial projects to achieve social status, and to be their boss i.e. to master himself.

Al-Nashmi, (2017) studied the effects of entrepreneurial characteristics (locus of control, self-confidence, need for achievement, independency and responsibility, risk-taking, creativity) on entrepreneurial intentions among business students in the University of Science and Technology, Yemen. The study found that there was a significant impact of entrepreneurial characteristics on the intentions to start new ventures among business students in the University of Science and Technology. Based on the regression analysis applied in the study, results also showed that students' locus of control and their creativity level were of the highest influencing variables on students' intentions, whereas self-confidence appeared to be the lowest influencing variable. 


\section{Comment on previous studies:}

The issue of entrepreneurship was of great interest to researchers, but the concept was not that clear to the staff at the organizational level. This may be because of absence of agreement on the concept itself. Consequently there were no clear strategies to demonstrate the extent to which this concept was adopted and taken care of. There is also a great interest in the concept of entrepreneurial intention. However, there is little understanding of the factors that affect students' intentions of becoming entrepreneurs and the relationship between entrepreneurship education and students' entrepreneurial attitudes and intentions. Similarly, little is known about differences in entrepreneurial intentions and attitudes among students belonging to different cultures and ethnicities, and this has been shown in some previous studies.

In terms of the objective of the study: It can be noted that previous studies sought to attain various objectives. Most of these studies focused on identifying the entrepreneurial characteristics among students (graduates or undergraduates) and tried to link these characteristics with entrepreneurial intentions (Zain, et al. 2010, Karimi, et. al. 2012, Al Haramsheh, H. E., 2016, Al-Nashmi, 2017). Some Studies expressed the entrepreneurial intention as entrepreneurship (Nasser and Al-Amri 2011), or entrepreneurial tendencies (Gibson et al., 2011), or establishment of entrepreneurial project (Zidan, 2011), or entrepreneurial orientation (Hill, 2011). Some studies added other variables like entrepreneurial education (Holienka, Holienková, \& Gál, 2015), while other use personal variables (Sultan, 2016).

In terms of variables of study: The previous studies also varied in their variables. That multiple variables have been used to measure entrepreneurial characteristics in the previous studies, but the current study adopted three main variables in relation to the entrepreneurial characteristics: (the need for achievement, self-efficacy, and self-control).The current study also differed from previous studies in the sense it has been conducted in number of universities in two different countries, Sudan and Oman, and this allows for making some comparisons.

\section{Research Problem and Questions}

This research study tries to find out the impact of entrepreneurial characteristics on entrepreneurial intention of undergraduate students in some universities of Sudan and Oman.

In light of the above, the following questions represent the main problem of the study:

- What is the level of availability of entrepreneurial characteristics of students in Sudanese and Omani Universities?

- What is the level of entrepreneurial intention of students in Sudanese and Omani Universities? 
- What is the impact of entrepreneurial characteristics on the entrepreneurial intention of students in Sudanese and Omani Universities?

Accordingly, the aim of this study is to identify the effect of entrepreneurial characteristics on the entrepreneurial intention of students in some Sudanese and Omani universities.

The importance of the study stems from the fact that it tries to add to the existing literature on entrepreneurship and entrepreneurial characteristics. The lack of empirical research in this respect in both Sudan and Oman increases the importance to this research. Another aspect which adds to the importance of the study is that it makes some comparison between students in different universities from two different countries.

\section{Hypothesis Development}

Based on the nature of the study and the information to be obtained from the views of students in a number of universities, and through the questions that the current study seeks to answer, the following hypotheses have been developed:

H1. There is a statistically significant impact of the entrepreneurial characteristics on the entrepreneurial intention of students in Sudanese and Omani Universities.

H1a: There is a statistically significant impact of the need for achievement on the entrepreneurial intention of students in Sudanese and Omani Universities

H1b. There is a statistically significant impact of Self-efficacy on the entrepreneurial intention of students in Sudanese and Omani Universities

H1c. There is a statistically significant impact of locus of control on the entrepreneurial intention of students in Sudanese and Omani Universities

$\mathrm{H} 2$. There are no statistically significant differences in the views of the respondents, concerning the impact relationship between the entrepreneurial characteristics and the entrepreneurial intention of students in Sudanese and Omani Universities, attributed to the university.

\section{Methodology}

In the light of the nature of the study and the objectives it sought to achieve, the researchers used the analytical descriptive method, which is based on the study of the phenomenon as it is in reality and describes it accurately and expresses it quantitatively to explain the impact of the independent variables on the dependent variable. This method is one of the main methods used in social researches, and it is the most appropriate method to describe the entrepreneurial characteristics of university students (the respondents). An 
attempt was made to interpret and analyze the data in order to reach results that serve the objectives of the study

The study population consists of university students in Sudan and Sultanate of Oman namely, University of Bahri (UoB) and Sudan International University (SIU) from Sudan and Dhofar University (DU) from Oman).

Primary sources included a questionnaire developed by the researchers as a tool for measuring study variables. In terms of the independent variable entrepreneurial characteristics (need for achievement, self-efficacy and selfcontrol) were based on the study of Sultan (2016) and Nasser \& Al-Amri (2011).

The dependent variable entrepreneurial intention was developed based on Zaidan (2011), Karimi, et. al. (2012), Ramadan (2012), Sulatn (2016), and Sacral, H. C. (2017).

The questionnaire was distributed to approximately 660 students in the three universities. A total of 574 of them were properly and consistently answered to be utilized in the analyses

The following table shows the demographic characteristics of the sample members.

Table 1: Demographic Information

\begin{tabular}{|l|l|l|l|}
\hline Variable & Category & Number & Percentage \\
\hline \multirow{4}{*}{ University } & Dhofar University (DU) & 127 & $22.1 \%$ \\
\cline { 2 - 4 } & Sudan International University (SIU) & 224 & $39.0 \%$ \\
\cline { 2 - 4 } & University of Bahri (UoB) & 223 & $38.9 \%$ \\
\cline { 2 - 4 } & Total & $\mathbf{5 7 4}$ & $\mathbf{1 0 0 \%}$ \\
\hline \multirow{5}{*}{ Age } & 20 yrs or less & 100 & $17.4 \%$ \\
\cline { 2 - 4 } & More than 20 - 25 yrs & 422 & $73.5 \%$ \\
\cline { 2 - 4 } & More than 25 - 30 yrs & 34 & $5.9 \%$ \\
\cline { 2 - 4 } & More than 30 yrs & 18 & $3.1 \%$ \\
\cline { 2 - 4 } & Total & $\mathbf{5 7 4}$ & $\mathbf{1 0 0 \%}$ \\
\hline \multirow{3}{*}{ Gender } & Male & 257 & $44.8 \%$ \\
\cline { 2 - 4 } & Female & 317 & $55.2 \%$ \\
\cline { 2 - 4 } & Total & $\mathbf{5 7 4}$ & $\mathbf{1 0 0}$ \\
\hline
\end{tabular}

Table 1, indicates that the highest percentage of students in the sample was from the Sudan International University by $39 \%$, followed by Bahri University with $38.9 \%$ of students in the sample and Dhofar University with $22.1 \%$. The table also shows that the percentage of female respondents in the sample was $55.2 \%$, while the percentage of males in the sample was $44.8 \%$. This reflects the current trend of increasing number of female students in institutions of higher education.

The percentage of the sample in the age group (more than $20-25$ years) was the highest and reached $73.5 \%$ of the total sample of the study sample, as well as in the age group (20 years and less) by $17.4 \%$. 
The results of the descriptive analysis of the demographic variables of the respondents of the study sample showed that the respondents are capable of understanding of the questionnaire questions and answering them objectively.

In the context of this study, the internal consistency of the study tool was thus evaluated based on the Cronbach's $\alpha$ internal consistency reliability value. The result of the reliability test showed that the study tool with a Cronbach's $\alpha$ coefficient of 0.886 , is satisfactorily consistent.

\section{Analysis of the Study Questions}

In this part of the study, the researchers analyzed the responses of the sample to the study questions as follows:

Question One: "What is the level of availability of entrepreneurial characteristics of students in Sudanese and Omani Universities?

Question Two: "What is the level of entrepreneurial intention of students in Sudanese and Omani Universities?

To answer these questions, the researchers calculated the arithmetical mean, the standard deviations, and the level of agreement, as follows:

Table 2: Means and standard deviations of the Study variables

\begin{tabular}{|l|l|l|l|}
\hline Variable & Mean & $\begin{array}{l}\text { Standard } \\
\text { Deviation }\end{array}$ & $\begin{array}{l}\text { The level of } \\
\text { Agreement }\end{array}$ \\
\hline The need for Achievement & 4.25 & .921 & Very High \\
\hline Self-efficacy & 4.35 & .930 & Very High \\
\hline Locus of Control & 4.04 & 1.003 & High \\
\hline Entrepreneurial Intention & 4.04 & 1.033 & High \\
\hline
\end{tabular}

Table 2 shows that the students have high level of entrepreneurial characteristics. Means of the five point Likert scale shows that individuals in the sample possess entrepreneurial characteristics. The need for achievement and Self-efficacy, were remarkably high with a mean of 4.25 and 4.35 out of 5. Locus of control and entrepreneurial intention showed a mean of 4.04.

\section{Hypothesis Testing}

In addition to what is provided by the descriptive statistics including, means, standard deviations and agreement levels for the independent and dependent variables, the inferential statistics will show the relationship and impact of the entrepreneurial characteristics on the entrepreneurial intentions of students in Sudanese and Omani universities. Therefore, in this part of the study the researchers examined the hypothesis of the study according to the responses of the sample of the study as follows:

H1: There is statistically significant impact of the entrepreneurial characteristics on the entrepreneurial intention of students in Sudanese and 
Omani Universities. This hypothesis included the basic premise for three subHypotheses which state that:

H1a: There is a statistically significant impact of the need for achievement on the entrepreneurial intention of students in Sudanese and Omani Universities

H1b. There is a statistically significant impact of Self-efficacy on the entrepreneurial intention of students in Sudanese and Omani Universities

H1c. There is a statistically significant impact of locus of control on the entrepreneurial intention of students in Sudanese and Omani Universities

To test these hypotheses, the researchers used multiple regression analysis, where all variables were introduced at once into the regression model, as follows:

Table 3: Model Summary

\begin{tabular}{|l|l|l|l|}
\hline Correlation & $\begin{array}{l}\text { Coefficient of } \\
\text { determination }\end{array}$ & $\begin{array}{l}\text { Adjusted Coefficient of } \\
\text { determination }\end{array}$ & Standard Error \\
\hline 0.618 & 0.382 & 0.379 & .550868 \\
\hline
\end{tabular}

The results of Table 3 indicate that the correlation coefficient between the entrepreneurial characteristics (independent variable) and the entrepreneurial intention (dependent variable) is (0.618), which indicates a positive relation between them. This means that if entrepreneur intention is to be enhanced, then it is necessary to have those entrepreneurial characteristics. The adjusted coefficient of determination of (0.379) indicates that entrepreneurial characteristics (independent variable) explains $(37.9 \%)$ of the change in the entrepreneur intention.

Table 4: ANOVA

\begin{tabular}{|l|l|l|l|l|l|}
\hline & $\begin{array}{l}\text { Sum } \\
\text { squares }\end{array}$ & Df. & $\begin{array}{l}\text { Mean } \\
\text { Squares }\end{array}$ & F & Sig \\
\cline { 1 - 4 } Regression & 91.149 & 3 & 30.383 & \multirow{2}{*}{117.419} & \multirow{2}{*}{.000} \\
\cline { 1 - 4 } Residual & 147.492 & 570 & .259 & & \\
\hline Total & 238.640 & 573 & & \\
\hline
\end{tabular}

The results of Table 4 show that the value of (f) for the regression was (117.419) and the statistical significance associated with it is (.000) which is below the statistical significance level (0.05). Based on this result, it can be said that the tendency of the entrepreneurial characteristics on the entrepreneurial intention is statistically significant at a level below (0.05). This means that there is a statistically significant impact at (0.05) level of at least one of the entrepreneurial characteristics on the entrepreneurial intention. In other words, there is a possibility of predicting the entrepreneurial intention of university students surveyed through some or all of the entrepreneurial characteristics. 
Table 5: Correlation Coefficient of the variables

\begin{tabular}{|l|l|l|l|l|}
\hline \multicolumn{1}{|c|}{ Source of Variation } & \multicolumn{1}{|c|}{$\begin{array}{c}\text { Regression } \\
\text { coefficient }\end{array}$} & Beta & T & Sig \\
\hline Constant & 0.846 & & 4.682 & .000 \\
\hline The need for Achievement & 0.154 & 0.140 & 3.568 & .000 \\
\hline Self-efficacy & 0.258 & 0.251 & 6.120 & .000 \\
\hline Locus of Control & 0.350 & 0.359 & 9.145 & .000 \\
\hline
\end{tabular}

Table 5 shows that the coefficient of the locus of control regression was the highest (3.50). The statistical significance associated with the value of (t) for this parameter is (.000), which is lower than the Sig. level of (0.05). The coefficient of self-efficacy regression of is (0.258) with a statistical significance level of (.000), which is less than the statistical significance level (0.05). Finally, the coefficient of regression for the need for achievement is (.154), and the statistical significance associated with the value of (t) is (.000), which is below the level of statistical significance (0.05). According to these data, there is a statistically significant impact at the statistical level (0.05), of the entrepreneurial characteristics of the surveyed university students on their entrepreneurial intention.

H2 There are no statistically significant differences in the views of the respondents concerning the impact of entrepreneurial characteristics and the entrepreneurial intentions of students in Sudanese and Omani Universities attributed to universities.

To test for differences in entrepreneurial characteristics and entrepreneurial intention ANOVA has been used and the results are as follows:

The results of Table 6 , show the analysis of the differences between the three universities (University of Bahri (UoB), Sudan International University (SIU) and Dhofar University (DU)) towards the entrepreneurial characteristics and entrepreneurial intention. The statistical significance associated with the value of $\mathrm{F}$ in the variables of locus of control and entrepreneurial intention, was lower than $(0.05)$ which shows that there are statistically significant differences in the views of respondents from the three universities towards these two variables. 
Table 7: Results of ANOVA test for entrepreneurial characteristics and entrepreneurial intention according to universities

\begin{tabular}{|c|c|c|c|c|c|c|}
\hline Dimension & $\begin{array}{l}\text { Source of } \\
\text { variation }\end{array}$ & $\begin{array}{l}\begin{array}{l}\text { Sum of } \\
\text { squares }\end{array} \\
\end{array}$ & Df. & $\begin{array}{l}\text { Mean } \\
\text { Squares }\end{array}$ & $\mathrm{F}$ & Sig. \\
\hline \multirow{3}{*}{$\begin{array}{l}\text { The need for } \\
\text { Achievement }\end{array}$} & Between groups & 0.564 & 2 & .282 & \multirow{3}{*}{0.824} & \multirow{3}{*}{0.439} \\
\hline & intra group & 195.518 & 571 & .342 & & \\
\hline & Total & 196.082 & 573 & & & \\
\hline \multirow{3}{*}{ Self-efficacy } & Between groups & 1.535 & 2 & .767 & \multirow{3}{*}{1.950} & \multirow{3}{*}{0.143} \\
\hline & intra group & 224.717 & 571 & .394 & & \\
\hline & Total & 226.252 & 573 & & & \\
\hline \multirow{3}{*}{ Locus of Control } & Between groups & 8.906 & 2 & 4.453 & \multirow{3}{*}{$\begin{array}{l}10.49 \\
8\end{array}$} & \multirow{3}{*}{0.000} \\
\hline & intra group & 242.205 & 571 & .424 & & \\
\hline & Total & 251.112 & 573 & & & \\
\hline \multirow{3}{*}{ Entrepreneurial Intention } & Between groups & 4.302 & 2 & 2.151 & \multirow{3}{*}{5.242} & \multirow{3}{*}{0.006} \\
\hline & intra group & 234.338 & 571 & .410 & & \\
\hline & Total & 238.640 & 573 & & & \\
\hline
\end{tabular}

To determine the direction of the differences arising in the above test in the variables of locus of control and entrepreneurial intention, a Tukey pairwise comparisons test was used as follows:

Table 8: Results of the Tukey test for differences between universities regarding the variable of locus of control

\begin{tabular}{|l|l|l|l|}
\hline University & University & Mean Difference & Sig. \\
\hline \multirow{2}{*}{ DU } & SIU & 0.13649 & 0.143 \\
\cline { 2 - 4 } & UoB & $0.32000^{*}$ & 0.000 \\
\hline \multirow{2}{*}{ SIU } & UoB & $0.18351^{*}$ & 0.008 \\
\hline
\end{tabular}

Table 8 , shows the results of the Tukey pairwise comparison test for the differences between the three universities towards the locus of control variable at the level of significance (0.05). The result showed differences between the views of students of DU and SIU, compared to views of Students UoB. It is observed that locus of control among students of DU and SIU higher than that of UoB students. This interesting result may be attributed to the fact that, while DU and SIU are private universities UoB is a public university. So the differences may be due to organizational culture (entrepreneurial orientation) between private and public universities.

Table 9: Results of the Tukey test for differences between universities regarding the variable of entrepreneurial intention

\begin{tabular}{|l|l|l|l|}
\hline University & University & Mean Difference & Sig. \\
\hline \multirow{2}{*}{ DU } & SIU & 0.12436 & 0.189 \\
\cline { 2 - 4 } & UoB & $0.22889^{*}$ & 0.004 \\
\hline SIU & UoB & 0.10453 & 0.197 \\
\hline
\end{tabular}

Table (9) presents the results of the Tukey pairwise comparison test for the differences between the three universities towards the entrepreneurial intention variable at the level of significance $(0.05)$. The result shows 
differences between the views of students of DU, compared to views of students SIU \& UoB. It can be said that the entrepreneurial intention among students of DU is higher than that of SIU \& UoB students. This may be attributed to some entrepreneurial environment in DU and Oman in general. The following table summarizes the acceptance or rejection of the hypotheses tested.

Table 10: Hypothesis' Acceptances or Rejections

\begin{tabular}{|l|l|}
\hline Hypothesis Statement & Status \\
\hline $\begin{array}{l}\text { H1. There is a statistically significant impact of the entrepreneurial characteristics on } \\
\text { the entrepreneurial intention of students in Sudanese and Omani Universities. }\end{array}$ & Accepted \\
\hline $\begin{array}{l}\text { H1a: There is a statistically significant impact of the need for achievement on the } \\
\text { entrepreneurial intention of students in Sudanese and Omani Universities }\end{array}$ & Accepted \\
\hline $\begin{array}{l}\text { HIb. There is a statistically significant impact of Self-efficacy on the entrepreneurial } \\
\text { intention of students in Sudanese and Omani Universities }\end{array}$ & Accepted \\
\hline $\begin{array}{l}\text { HIc. There is a statistically significant impact of locus of control on the entrepreneurial } \\
\text { intention of students in Sudanese and Omani Universities }\end{array}$ & Accepted \\
\hline $\begin{array}{l}\text { H3. There are no statistically significant differences in the views of the respondents, } \\
\text { concerning the impact relationship between the entrepreneurial characteristics and the } \\
\text { entrepreneurial intention of students in Sudanese and Omani Universities, attributed to } \\
\text { the university. }\end{array}$ & \\
\hline
\end{tabular}

\section{Conclusion}

The importance of the study is that it explains the entrepreneurial characteristics of university students in Sudan and Oman. Its main objective is to identify those entrepreneurial characteristics that have more impact on their willingness to establish their own businesses rather than waiting in the cue of conventional jobs.

The results of the study indicated that the level of the availability of the three main entrepreneurial characteristics, need for achievement, selfefficacy and locus of control were found to very high, very and high, respectively. In addition the availability level of the entrepreneurial intention among the university students surveyed was also high measured by an average mean of 4.04. These results indicate that students of DU, SIU and UoB enjoy the characteristics of entrepreneurs.

The results of the study showed that the entrepreneurial characteristics of students significantly affect their entrepreneurial intention, which is in line with the result of SmartPLS path analysis. This increases the possibility of students engaging in self-employment activities and entrepreneurial work if the necessary requirements of entrepreneurial work are available.

The result of the analysis of MANOVA showed no statistically significant differences in views of the students in DU, SIU and UoB concerning the impact relationship between the independent variables and the dependent variable. However, the result shows that there are statistically 
significant differences in the views of the respondents according their universities, concerning the locus of control and entrepreneurial intention. The analysis showed that locus of control among students of DU and SIU was higher than that of UoB students. Furthermore, it was found that the entrepreneurial intention among students of DU was higher than that of SIU \& UoB students.

\section{Implications of the study}

The study showed the importance of entrepreneurial characteristics as predictors for entrepreneurial intentions of the university students. Therefore, university leaders should be aware of their student's both entrepreneurial characteristics and intentions. In this regard building an entrepreneurial orientation in universities is must through establishing entrepreneurship centers, adopting entrepreneurial support policies and engaging in partnerships with other entrepreneurial supporting bodies.

\section{Limitations and Future Research Directions}

The research paper analyzed the impact of only a limited number of entrepreneurial characteristics as the main motivators for entrepreneurial intention. There are definitely other characteristics the study doesn't cover, which might have significant influence on entrepreneurial intention. Another limitation is that the study is limited to the small number of universities. Only three universities are chosen for the study (two from Sudan and One from Oman). Future researchers can consider these variables as well as they can increase both the sampling area and sample size to reveal more representative results

\section{References:}

1. Basu, A., \& Virick, M. (2008). Assessing Entrepreneurial Intentions Amongst Students: A Comparative Study. In 12th Annual Meeting of the National Collegiate Inventors and Innovators Alliance, Dallas, USA (pp. 19-21). Available at http://works.bepress.com/meghna_virick/18/

2. Al Haramsheh, H. E. (2016). Under Graduate Business Administration Students, Tendencies Towards Initiating Small Entrepreneurship Businesses (Zarqa University Student as a Case Study). Zarqa Journal for Research and Studies in Humanities, 16(1), 141 - 151.

3. Ajzen, I. (2002). Perceived behavioral control, self-efficacy, locus of control, and the theory of planned behavior. Journal of Applied Social Psychology, 32, 1-20.

4. Ajzen, I. (2005). Attitudes, personality and behavior. 2nd ed. England: Open University Press (McGraw-Hill). 
5. Al-Kasabahs, M. (2008). Preparing for an entrepreneurship: An Exploratory Study on Business students of AL- Petra University (Master's thesis, AL- Petra University, Amman, Jordan).

6. AL-Najjar, .Faiz, and AL-Ali, AAbulsattar, (2006). Entrepreneurship and Small Business Management. Dar Al Hamed Publishing and Distribution. Jordan

7. Al-Nashmi, M. (2017). The impact of entrepreneurial characteristics on the intention of administrative sciences students to start new ventures -University of Science and Technology-. The Arab Journal for Quality Assurance in Higher Education, 10(5), 103-119. doi:10.20428/ajqahe.10.5.5

8. Al-Sheikh, F. N., Melham, Y., \& Al-Cakelike, W. M. (2009). Entrepreneurial women in Jordan: Traits and characteristic. -Jordan Journal of Business Administration, 5(4).

9. Barringer, B. R., \& Ireland, R. D. (2016). Entrepreneurship: Successfully launching new ventures. Upper Saddle River: Prentice Hall.

10. Filion, Louis J. (1998). From entrepreneurship to entreprenology: The emergence of a new discipline. Erscheinungsort nicht ermittelbar: Verlag nicht ermittelbar.

11. Gürol, Y., \& Atsan, N. (2006). Entrepreneurial characteristics amongst university students. Education + Training, 48(1), 25-38. Doi: 10.1108/00400910610645716

12. Holienka, M., Holienková, J., \& Gál, P. (2015). Entrepreneurial Characteristics of Students in Different Fields of Study: a View from Entrepreneurship Education Perspective. Acta Universitatis Agriculturae et Silviculturae Mendelianae Brunensis, 63(6), 18791889. Doi: 10.11118/actaun201563061879

13. Hussain, G. I. (2013). Enhancement the Role of Entrepreneurship Characteristics in Organizational Commitment: An Explanatory Study at the General Company of Electrical Industries-Diyala Province. AL GHAREE for Economics and Administration Science, 9 (26), 67 -94.

14. Gibson, D, Harris, M, L, mick, T, D, \& Bburkhalter, T, M. (2011). Comparing the entrepreneurial attitudes of university and community college student. Journal of higher education theory and practice. 11(2), 11-19.

15. Gupta, Vishal K. and Bhawe, Nachiket, the Effect of Gender Stereotype Assimilation and Contrast on Entrepreneurial Intention (January 2007). Available at SSRN: https://ssrn.com/abstract=958624

16. Hatten, T. S. (2016). Small business management: Entrepreneurship and beyond (5th ed.). South-Western, Cengage Learning. 
17. Hill, E, S. (2011). The impact of entrepreneurship education- an exploratory study of MBA graduates in Ireland. Thesis for degree of master of business studies. University of Limerick.

18. Indrasari, M., Purnomo, R. B., Syamsudin, N., \& Yunus, E. (2018). Development Entrepreneurship Intention among Students. IJEBD (International Journal of Entrepreneurship and Business Development), 1(2), 146-154. doi:10.29138/ijebd.v1i2.556

19. Karimi, S., Biemans, H. J., Lans, T., Mulder, M., \& Chizari, M. (2012). The Role of Entrepreneurship Education in Developing Students' Entrepreneurial Intentions. SSRN Electronic Journal. doi:10.2139/ssrn.2152944

20. Kaufmann, P. J., \& Dant, R. P. (1999). Franchising and the domain of entrepreneurship research. Journal of Business Venturing, 14(1), 5-16. Doi: 10.1016/s0883-9026(97)00095-5

21. Kusmintarti, A., Asdani, A. and Riwajanti, N.I. (2017) 'The relationship between creativity, entrepreneurial attitude and entrepreneurial intention (case study on the students of State Polytechnic Malang)', Int. J. Trade and Global Markets, Vol. 10, No. 1, pp.28-36.

22. Longenecker, J. G., $\quad$ Petty, J. W., Palich, L. E., \& Hoy, F. (2017). Small business management: Launching \& growing entrepreneurial ventures.

23. Mohammad, A. S., \& Mahmoud, A. M. (2014). Measuring the Level of Entrepreneurship Among Students of Taif University and the Role of the University in its Development. Scientific Research in Education, 1(15), 549 - 599. Doi: 777517

24. Mohd, R., Yahya, K. K., \& Kammaruddin, B. H. (2012). The Moderating Effect of Environment on the Relationship between SelfEfficacy and Entrepreneurial Orientation among Malay SMEs in Manufacturing Industry. In Cambridge IGCSE Business Studies Revision Guide. Cambridge, England: Cambridge University Press.

25. Nasser, M. J., \& AL Amri, G. (2011). Measurement of entrepreneurial characteristics among graduate students in business administration and their impact on entrepreneurial work: a comparative study. Journal of Damascus University for Economic and Legal Sciences, 27(4).

26. Ozaralli, N., \& Rivenburgh, N. K. (2016). Entrepreneurial intention: antecedents to entrepreneurial behavior in the U.S.A. and Turkey. Journal of Global Entrepreneurship Research,6(1). Doi: 10.1186/s40497-016-0047-x

27. Ramdan, R. (2013). The Elements of the external environment and their relation with the entrepreneurial intention of university students using the Global Entrepreneurship Monitor. Journal of Damascus 
University for Economic and Legal Sciences -, 29(1). Retrieved from http://damasuniv.edu.sy/mag/law/index.php?lang=1

28. Siva rajah, K., \& Achchuthan, S. (2013). Entrepreneurial Intention among Undergraduates: Review of Literature. European Journal of Business and Management, 5(5), 172-186. Retrieved from ISSN 22221905

29. Sacral, H. C. (2017). The Relationship between Entrepreneurial Characteristics and Entrepreneurial Intention. doi:10.15405/epsbs.2017.12.02.31

30. Stajkovic, A. D., \& Luthans, F. (1998). Self-efficacy and work-related performance: A meta-analysis. Psychological Bulletin, 124(2), 240261. doi:10.1037/0033-2909.124.2.240

31. Sulatn, S. M., (2016). Availability Level of Entrepreneurial Characteristics and its Relationship to Some Personal Variables: An Empirical Study on Undergraduate Students Business Administration in the Southern West Bank Universities. IUG Journal of Economics and Business Studies, 24(2), 102-123. Doi: 10.12816/0035795

32. Souitaris, V., Zerbinati, S., \& Al-Laham, A. (2007). Do entrepreneurship programs raise entrepreneurial intention of science and engineering students? The effect of learning, inspiration and resources. Journal of Business Venturing,22(4), 566-591. doi:10.1016/j.jbusvent.2006.05.002

33. Wilson, F., D. Marlino, and J. Kickul. 2004. Our entrepreneurial future: Examining the diverse attitudes and motivations of teens across gender and ethnic identity. Journal of Developmental Entrepreneurship 9 (3): 177-197.

34. Zain, Z, Akram, A \& Ghani, E, (2010). Entrepreneurship Intention among Malaysian Business students, CANADIAN social science, 3 (6).

35. Zaidan, Amr A., (2011), The Effect of Entrepreneurial Characteristics of Egyptian Universities Students on their Possibilities for establishing their own Projects after Graduation. The Arab Journal for Management Sciences, 31 (1) 